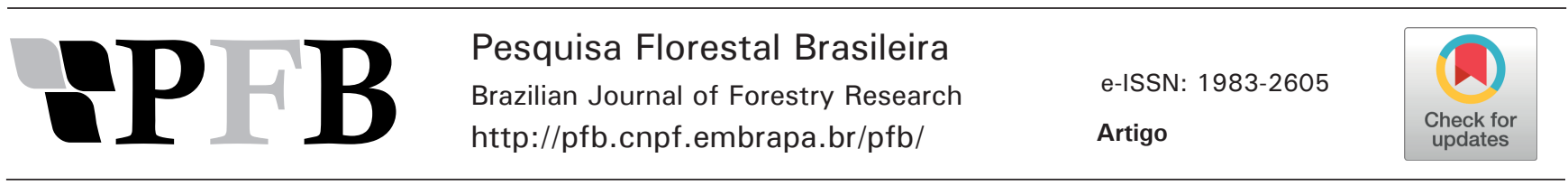

\title{
Fitorreguladores na calogênese e rizogênese em Eugenia involucrata
}

\author{
Diego Pascoal Golle ${ }^{1}$ (D), Lia Rejane Silveira Reiniger ${ }^{2}$ (D), Charlene Moro Stefanel${ }^{2}$ (D), Caetano Miguel Lemos Serrote ${ }^{2}$ (D) \\ ${ }^{1}$ Universidade de Cruz Alta, Rodovia Municipal Jacob Della Méa, km 5.6, CEP 98005-972, Cruz Alta, RS, Brasil \\ 2Universidade Federal de Santa Maria, Departamento de Fitotecnia, Avenida Roraima, 1000, CEP 97105-900, Santa Maria, RS, Brasil
}

\section{"Autor correspondente: \\ liarsr@ufsm.br}

Termos para indexação:

Biotecnologia vegetal

Organogênese

Propagação vegetativa

Index terms:

Plant biotechnology

Organogenesis

Vegetative propagation

Histórico do artigo:

Recebido em 19/02/2019

Aprovado em 12/12/2019

Publicado em 30/09/2020
Resumo - Este trabalho objetivou avaliar o efeito de fitorreguladores na calogênese e rizogênese em discos foliares de Eugenia involucrata. Foram testadas, em dois experimentos, combinações de ácido naftalenoacético (ANA) e 6-benzilaminopurina (BAP) e de 2,4-diclorofenoxiacético (2,4-D) e BAP. Aos 45 dias de cultivo todos os tratamentos formaram calos, principalmente naqueles em que foram empregados ANA isolado e, também, combinado com BAP, bem como 2,4-D e BAP (5:5 e 10:10 $\mu \mathrm{M})$. Apenas ANA isolado $(10 \mu \mathrm{M})$ induziu rizogênese. Aos 90 dias de cultivo pôde-se perceber melhor o efeito dos fitorreguladores, observando-se que 2,4-D e BAP (5:5 e 10:10 $\mu \mathrm{M}$ ) favoreceram a calogênese, enquanto para rizogênese o melhor tratamento foi com $10 \mu \mathrm{M}$ de ANA. É possível mediar processos de desdiferenciação e rediferenciação celular a partir de discos foliares de Eugenia involucrata.

\section{Growth regulators on callogenesis and rhizogenesis in Eugenia involucrata}

\begin{abstract}
This study evaluated the effect of growth regulators on callogenesis and rhizogenesis in Eugenia involucrata. In two experiments, we tested the naphthaleneacetic acid (NAA) and 6-benzylaminopurine (BAP), and 2,4-dichlorophenoxyacetic acid $(2,4-D)$ and BAP associations. After 45 days of culture, all treatments formed calli, however, those treatments with NAA (alone or combined with BAP) and 2,4-D combined with BAP $(5: 5$ and 10:10 $\mu \mathrm{M})$ presented the best results. Only the use of NAA at $10 \mu \mathrm{M}$ induced rhizogenesis. At 90 days of culture, the effect of phytoregulators was most evident, where 2,4-D combined with BAP (5:5 and 10:10 $\mu \mathrm{M})$ were more favorable for callogenesis while $10 \mu \mathrm{M}$ NAA were more favorable for rhizogenesis. These results indicate that cell dedifferentiation and re-differentiation processes are achievable from leaf explants of Eugenia involucrata.
\end{abstract}

\section{Introdução}

A cerejeira-do-mato (Eugenia involucrata D.C., Myrtaceae) possui madeira de excelente qualidade e durabilidade, sendo utilizada para a fabricação de móveis, lenha, carvão e cabos de ferramentas. É uma espécie ornamental, com boa formação de copa, que pode ser utilizada na arborização urbana, além de possuir propriedades medicinais (Lorenzi, 2009; Backes \& Irgang, 2009). Inobstante tais qualidades, seu uso tem sido escasso, notadamente pela falta de conhecimentos sobre sua propagação e variabilidade genética. 
A produção de mudas via sementes é dificultada por apresentar características recalcitrantes e o processo de deterioração de suas sementes ocorrer após decorridas apenas duas semanas de armazenamento (Carvalho, 2014). Nesse sentido, a propagação vegetativa, em especial pelo emprego de técnicas da cultura de tecidos, pode se constituir em alternativa importante para a obtenção de mudas dessa espécie.

As populações florestais, de uma maneira geral, vêm sendo expostas a um intenso processo de fragmentação. Como a cerejeira-do-mato é classificada como autógama (Carvalho, 2014), a expectativa é que a variabilidade genética existente em remanescentes naturais da espécie seja reduzida. De maneira similar ao que já foi afirmado em relação à propagação, a cultura de tecidos também pode ser útil quando se deseja ampliar o reservatório de variabilidade genética. Nesse sentido, a propagação in vitro via organogênese indireta, que inclui uma fase calogênica, pode conduzir ao aparecimento de variantes somaclonais de eventual interesse, que poderiam ser selecionados e, eventualmente, clonados. Adicionalmente, os calos obtidos podem ser fonte de moléculas bioativas das plantas (Alencar, 2015).

Com o emprego da indução à variação somaclonal, o tempo necessário para a obtenção de plantas com novas características pode ser extremamente reduzido ao comparar-se com o uso de técnicas clássicas de melhoramento, em especial em plantas lenhosas, em que o tempo necessário para atingir a maturidade é muito longo (Shen et al., 2007). Além disso, por meio do cultivo de células in vitro, que podem ser geradas a partir de calos, pode-se utilizar métodos de transformação genética para a introdução de características desejadas nas plantas, sendo uma condição fundamental para esta finalidade o desenvolvimento de protocolos eficientes de calogênese e organogênese (Pasquali \& Zanettini, 2007).

Para a obtenção de calos devem ser estudadas as condições mais adequadas para a sua indução, como o balanço entre auxinas e citocininas no meio nutritivo, que constitui a temática do presente estudo. Na maioria das vezes, a interação entre esses fitorreguladores é responsável pela alta indução de calos (Carvalho et al., 2015), no entanto, alterações nesse balanço podem conduzir a rotas organogênicas, que promovem a formação de raízes, de brotos ou gemas adventícias (Termignoni, 2005).

Em espécies florestais, a comunidade científica tem demonstrado interesse na elucidação de aspectos relacionados ao balanço de fitorreguladores, a exemplo de Morinda citrifolia (Baque et al., 2010), Caesalpinia echinata (Werner et al., 2010; Aragão et al., 2011), Hyptis leucocephala (Pereira et al., 2012), Ilex paraguariensis (Stachevski et al., 2013), Campomanesia adamantium (Rossato et al., 2015), entre outras. Nessas espécies, os balanços entre auxinas e citocininas têm conduzido tecidos à formação de calos e, igualmente, de outras estruturas, como raízes, brotos e embriões em Litchi chinensis (Ma et al., 2009) e Passiflora cincinnata (Silva et al., 2009; Pinto et al., 2010).

O presente trabalho teve como objetivo avaliar o efeito de diferentes combinações de concentrações de fitorreguladores, sobre a calogênese e a rizogênese in vitro em discos foliares de cerejeira-do-mato (Eugenia involucrata DC.).

\section{Material e métodos}

Foram conduzidos dois experimentos no Laboratório de Cultura de Tecidos Vegetais pertencente ao Núcleo de Biotecnologia e Melhoramento da Universidade Federal de Santa Maria, em Santa Maria, Rio Grande do Sul.

As plantas doadoras dos explantes utilizados nos experimentos encontravam-se em desenvolvimento em casa de vegetação, sem controle de temperatura e umidade, e possuíam, na época, aproximadamente 2 anos de idade. As plantas foram mantidas em vasos plásticos com $22 \mathrm{~cm}$ de altura e $24 \mathrm{~cm}$ de diâmetro (capacidade aproximada de $8 \mathrm{~L}$ ) contendo o substrato Plantmax $^{\circledR}$ (constituído de casca de pinus, vermiculita de granulometria fina e superfina e húmus). Além de irrigações diárias, a cada dois meses essas plantas receberam $400 \mathrm{~mL}$ de solução à base de nitrogênio, fósforo e potássio (N-P-K: 5-20-20) a $1 \mathrm{~g} \mathrm{~L}^{-1}$ e, a cada 15 dias, igual volume de solução de nitrogênio (ureia) na mesma concentração. Quinzenalmente, as plantas foram pulverizadas com solução composta por água destilada acrescida de $1 \mathrm{~g} \mathrm{~L}^{-1}$ de Cercobin700PM ${ }^{\circledR}$ (thiophanato metílico) e $100 \mathrm{mg} \mathrm{L}^{-1}$ de sulfato de estreptomicina, até atingir encharcamento completo.

Foram coletadas folhas jovens completamente expandidas, a partir de regiões medianas das plantas e dos ramos. Durante a coleta, o material foi acondicionado por $30 \mathrm{~min}$ em água destilada contendo $1 \mathrm{~g} \mathrm{~L}^{-1} \mathrm{de}$ Benlate $500^{\circledR}$ (benomyl) e $100 \mathrm{mg} \mathrm{L}^{-1}$ de sulfato de estreptomicina. No laboratório, as folhas passaram pelo seguinte processo de desinfestação em câmara de fluxo 
laminar: imersão por 5 min em água corrente; agitação por $30 \mathrm{~s}$ em solução de etanol a $70 \%$ (v/v); enxágue em água destilada e autoclavada; agitação por $15 \mathrm{~min}$ em solução de hipoclorito de sódio $(\mathrm{NaClO})$ a $1,5 \%(\mathrm{v} / \mathrm{v})$ acrescida de três gotas de detergente comercial e, por fim, um triplo enxágue em água destilada e autoclavada.

O primeiro experimento foi conduzido em delineamento inteiramente casualizado com 12 tratamentos e 10 repetições. Cada unidade experimental foi composta por um frasco com capacidade para $150 \mathrm{~mL}$, contendo $30 \mathrm{~mL}$ de meio nutritivo e três discos foliares, perfazendo um total de 120 unidades experimentais e 360 explantes inoculados. Os discos foliares foram obtidos com o uso de um cortador metálico cilíndrico, com aproximadamente $1 \mathrm{~cm}$ de diâmetro, o qual foi previamente esterilizado em autoclave durante $40 \mathrm{~min}$.

O meio nutritivo utilizado foi o MS (Murashige \& Skoog, 1962) acrescido de $30 \mathrm{~g} \mathrm{~L}^{-1}$ de sacarose e $7 \mathrm{~g} \mathrm{~L}^{-1}$ de ágar (Acumedia ${ }^{\circledR}$ ), além de ácido naftalenoacético (ANA), 6-benzilaminopurina (BAP) e ácido 2,4-diclorofenoxiacético (2,4-D), conforme o tratamento. Os tratamentos consistiram das seguintes combinações de concentrações (em proporções): a) de ANA e BAP: 5:0; 0:5; 10:0; 0:10; 5:5; 5:10; 10:5; 10:10 (em $\mu \mathrm{M})$, respectivamente; e b) de 2,4-D e BAP: 5:5; 5:10; 10:5; e 10:10 (em $\mu \mathrm{M})$, respectivamente. O emprego isolado de 2,4-D não foi avaliado, devido aos resultados observados em experimentos anteriores não terem apresentado resposta in vitro.

$\mathrm{O}$ pH do meio nutritivo foi ajustado para 5,8 após a inclusão dos fitorreguladores e antes da adição de ágar. Os frascos contendo meio de cultura foram autoclavados por 20 min a temperatura de $121^{\circ} \mathrm{C} \mathrm{e} 1,5 \mathrm{~atm}$ de pressão, inoculados e vedados com papel alumínio. Os frascos foram mantidos em sala de cultivo com temperatura controlada em $25 \pm 3{ }^{\circ} \mathrm{C}$ e acondicionados em caixas de papel cobertas por plástico escuro, visando promover a ausência total de luminosidade durante todo o período de cultivo.

Aos 45 dias, foram avaliadas as variáveis: formação de calos (porcentagem de calos formados, independente de seu estádio de desenvolvimento), rizogênese (porcentagem de explantes que apresentaram formação de raízes) e oxidação fenólica (porcentagem de explantes que apresentavam qualquer aspecto oxidado, visualizada pela coloração do explante, mesmo quando o aspecto oxidativo não inibiu o seu desenvolvimento). À observação qualitativa dos calos foi atribuída a seguinte escala numérica: 0 = ausência de formação calogênica; 1 = formação branda de calos; 2 = formação calogênica em toda a bordadura dos discos foliares; e 3 = formação calogênica com crescimento secundário. Foram obtidas médias das notas atribuídas aos calos formados em cada tratamento, o que constituiu uma variável adicional avaliada (Figura 1).

No segundo experimento, realizado após 45 dias do primeiro, os tratamentos utilizados foram os mesmos do primeiro. Todavia, foram utilizados como explantes iniciais apenas os discos foliares que formaram calos ou calos rizogênicos, preservando-se a identidade do tratamento de origem e, assim, permitindo uma acurada observação do desenvolvimento dos calos após 90 dias de cultivo in vitro. Considerou-se como um experimento separado - e não um subcultivo - pelo fato de se ter selecionado os explantes, excluindo-se aqueles que não desenvolveram calos no período da primeira avaliação e, desta forma, reduzindo-se o efeito da variabilidade genética e melhorando-se a aproximação dos resultados apenas para os tratamentos utilizados. Este experimento foi conduzido em delineamento inteiramente casualizado, com número variável de repetições (de três a seis) em um total de 53 unidades experimentais, compostas por um frasco contendo três explantes, totalizando 159 explantes.

Foram avaliadas, após 90 dias de cultivo (considerando-se os 30 dias do experimento anterior), as mesmas variáveis anteriomente relatadas, exceto a formação de calos, uma vez que somente foram transferidos discos foliares que apresentavam essas estruturas. À escala de notas atribuídas aos calos foi acrescido o valor "4", quando houve crescimento calogênico abundante, cobrindo a maior parte da área do explante (Figura 1). Igualmente, foi incluída a variável incremento de formação calogênica, obtida por meio da pesagem dos explantes em balança analítica e do cálculo da relação entre massa fresca inicial e final ((MI $(M F) \times 100)$. No experimento anterior esta variável não havia sido incluída, para evitar eventuais contaminações microbianas nos explantes, oriundas de sua manipulação durante as avaliações.

A normalidade dos erros foi avaliada pelo teste de Kolmogorov-Smirnov e a homogeneidade de variâncias pelo teste de Bartlett. Os dados, sempre que necessário, foram submetidos à transformação pela função $\sqrt{x+0,5} \mathrm{e}$, na sequência, à análise de variância. As médias foram comparadas por meio do teste de Scott-Knott ao nível 


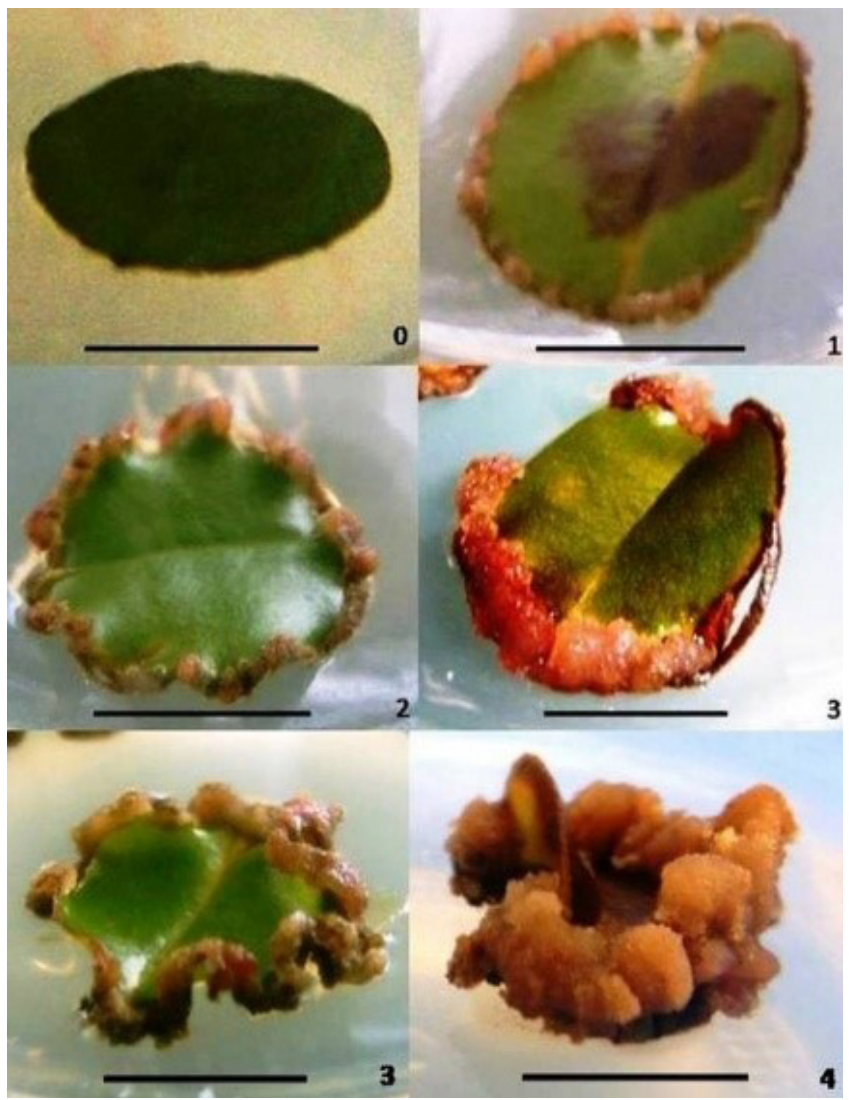

Figura 1. Intensidade de formação de calos em discos foliares de Eugenia involucrata, após 45 dias de cultivo in vitro em meio nutritivo MS e respectivas notas atribuídas aos calos, em que: 0 = ausência de formação de calos; 1 = início de formações calogênicas nas bordas dos discos foliares; 2 = formação calogênica em toda a bordadura do disco foliar; 3 = formação de calos com crescimento secundário; e $4=$ calos com crescimento abundante, cuja avaliação ocorreu apenas no segundo experimento, após 90 dias de cultivo in vitro. Barra $=1 \mathrm{~cm}$.

Figure 1. Intensity of callogenesis in leaf discs of Eugenia involucrata, after 45 days of in vitro culture in MS nutrient medium, and respective scores attributed to callus formation, where: $0=$ absence of callus formation; 1 = beginning of callus formation at the leaf discs edges; 2 = callogenic formation throughout the leaf disc border; 3 = formation of calli with secondary growth; and $4=$ calli with abundant growth, which evaluation occurred only in the second experiment, after 90 days of in vitro culture. $\mathrm{Bar}=1 \mathrm{~cm}$. de $5 \%$ de probabilidade de erro. Os dados apresentados foram aqueles efetivamente observados. As análises foram executadas com auxílio do programa estatístico SISVAR (Ferreira, 2011).

\section{Resultados}

No primeiro experimento, observaram-se diferenças significativas para todas as variáveis analisadas, exceto para a oxidação fenólica $(\mathrm{p}=0,2904)$, que apresentou média geral reduzida de $3,55 \%$. Na Tabela 1 são apresentadas as médias observadas para porcentagem de formação de calos ( $\mathrm{p}=0,0116)$, das notas atribuídas aos calos $(p=0,0003)$ e da porcentagem de calos rizogênicos $(\mathrm{p}=0,0000)$.

$\mathrm{Na}$ formação calogênica, os tratamentos contendo apenas ANA, tanto a $5 \mu \mathrm{M}(70,3 \%)$ como a $10 \mu \mathrm{M}$ (75,0\%) ou em combinação com BAP, em todas as proporções testadas, apresentaram os melhores resultados e não diferiram significativamente entre si (Tabela 1). Estes, por sua vez, também não diferiram dos tratamentos contendo 2,4-D + BAP, nas proporções 5:5 e 10:10 em $\mu \mathrm{M}$, e todos foram superiores ao uso de BAP a 5 e a $10 \mu \mathrm{M}$ e às combinações de 2,4-D + BAP a 5:10 e 10:5 em $\mu \mathrm{M}$, os quais, por sua vez, não diferiram entre si (Tabela 1).

Quanto às médias das notas atribuídas aos calos (Figura 1 e Tabela 1), o comportamento observado foi semelhante à formação de calos, sendo os tratamentos compostos por ANA a 5 e a $10 \mu \mathrm{M}$ e as combinações ANA + BAP de 5:5, 5:10, 10:5, 10:10 em $\mu \mathrm{M}$; bem como os tratamentos contendo 2,4-D + BAP nas proporções de 5:5 e 10:10 em $\mu \mathrm{M}$, àqueles que apresentaram as maiores médias, as quais não diferiram entre si. Observou-se que foram superiores aos tratamentos compostos por BAP a 5 e a $10 \mu \mathrm{M}$ e destacaram-se em relação às combinações 2,4-D + BAP de 5:10 e 10:5 em $\mu \mathrm{M}$, as quais resultaram nas menores médias de notas (Tabela 1). Assim, foi possível inferir que os tratamentos que incluíram BAP, nas concentrações testadas e isolado de auxinas, não foram adequados à formação de calos nos explantes, mesmo quando aumentada a concentração de 5 para $10 \mu \mathrm{M}$. A combinação 2,4-D + BAP foi benéfica à formação de calos nos discos foliares aos 
Tabela 1. Efeito de diferentes balanços dos fitorreguladores: ácido naftalenoacético (ANA), ácido 2,4-diclorofenóxiacético (2,4-D) e 6-benzilaminopurina (BAP) adicionados ao meio nutritivo MS sobre a formação de calos rizogênicos e não rizogênicos em discos foliares de Eugenia involucrata, após 45 dias de cultivo in vitro.

Table 1. Effect of different growth regulators balances: naphthaleneacetic acid (ANA), 2,4-dichlorophenoxyacetic acid (2,4-D) and 6-benzylaminopurine (BAP) added to MS nutrient medium on rhizogenic and non-rhizogenic callus formation, in leaf discs of Eugenia involucrata, after 45 days of in vitro culture.

\begin{tabular}{|c|c|c|c|}
\hline Tratamentos & Formação de calos (\%) & Nota & Calos rizogênicos (\%) \\
\hline $5 \mu \mathrm{M}$ de ANA & $70,3 \mathrm{a}^{*}$ & $1,70 \mathrm{a}$ & $0,0 \mathrm{~b}$ \\
\hline $5 \mu \mathrm{M}$ de BAP & $45,8 \mathrm{~b}$ & $0,45 \mathrm{~b}$ & $0,0 \mathrm{~b}$ \\
\hline $10 \mu \mathrm{M}$ de ANA & $75,0 \mathrm{a}$ & $1,50 \mathrm{a}$ & $18,3 \mathrm{a}$ \\
\hline $10 \mu \mathrm{M}$ de BAP & $48,1 \mathrm{~b}$ & $0,52 \mathrm{~b}$ & $0,0 \mathrm{~b}$ \\
\hline $5 \mu \mathrm{M}$ de $\mathrm{ANA}+5 \mu \mathrm{M}$ de BAP & $70,3 \mathrm{a}$ & $1,44 \mathrm{a}$ & $0,0 \mathrm{~b}$ \\
\hline $5 \mu \mathrm{M}$ de $\mathrm{ANA}+10 \mu \mathrm{M}$ de BAP & $73,4 \mathrm{a}$ & $1,33 \mathrm{a}$ & $0,0 \mathrm{~b}$ \\
\hline $10 \mu \mathrm{M}$ de $\mathrm{ANA}+5 \mu \mathrm{M}$ de BAP & $80,9 \mathrm{a}$ & $1,61 \mathrm{a}$ & $0,0 \mathrm{~b}$ \\
\hline $10 \mu \mathrm{M}$ de $\mathrm{ANA}+10 \mu \mathrm{M}$ de BAP & $62,5 \mathrm{a}$ & $1,17 \mathrm{a}$ & $0,0 \mathrm{~b}$ \\
\hline $5 \mu \mathrm{M}$ de $2,4-\mathrm{D}+5 \mu \mathrm{M}$ de BAP & $85,2 \mathrm{a}$ & $1,77 \mathrm{a}$ & $0,0 \mathrm{~b}$ \\
\hline $5 \mu \mathrm{M}$ de $2,4-\mathrm{D}+10 \mu \mathrm{M}$ de BAP & $50,0 \mathrm{~b}$ & $0,89 \mathrm{~b}$ & $0,0 \mathrm{~b}$ \\
\hline $10 \mu \mathrm{M}$ de $2,4-\mathrm{D}+5 \mu \mathrm{M}$ de BAP & $50,0 \mathrm{~b}$ & $0,74 \mathrm{~b}$ & $0,0 \mathrm{~b}$ \\
\hline $10 \mu \mathrm{M}$ de $2,4-\mathrm{D}+10 \mu \mathrm{M}$ de BAP & $66,6 \mathrm{a}$ & $1,10 \mathrm{a}$ & $0,0 \mathrm{~b}$ \\
\hline Média & 64,8 & 1,19 & 1,5 \\
\hline $\mathrm{CV}(\%)$ & 13,2 & 21,78 & 6,4 \\
\hline
\end{tabular}

*Médias seguidas pela mesma letra na coluna não diferem entre si pelo teste de Scott-Knott ao nível de 5\% de probabilidade de erro.

45 dias de cultivo, notadamente quando as proporções estavam equilibradas $(5: 5 ; 10: 10 \mathrm{em} \mu \mathrm{M})$, privilegiando a calogênese.

Aos 45 dias de cultivo, apenas o tratamento composto por ANA a $10 \mu \mathrm{M}$ apresentou formação de raízes nos calos, o que ocorreu em 18,3\% dos explantes. Os demais tratamentos não induziram a formação de estruturas radiculares a partir dos calos formados.

No experimento II, aos 90 dias de cultivo dos discos foliares, não houve efeito significativo $(\mathrm{p}=0,2191)$ dos tratamentos em relação à oxidação fenólica, sendo observada uma média reduzida $(5,0 \%)$. Entretanto, foram observadas diferenças significativas entre as médias das notas atribuídas aos calos $(\mathrm{p}=0,0000)$, incremento da formação calogênica em porcentagem $(\mathrm{p}=0,0000)$ e porcentagem de calos rizogênicos $(\mathrm{p}=0,0004)$ (Tabela 2).

Os tratamentos contendo apenas ANA a $5 \mu \mathrm{M}$ e a $10 \mu \mathrm{M}$, bem como as combinações ANA + BAP de 5:5, 5:10, 10:5 e 10:10 em $\mu \mathrm{M}$, além de 2,4-D + BAP de 5:5 e 10:10 em $\mu \mathrm{M}$ foram aqueles que apresentaram as melhores notas e não diferiram entre si (Tabela 2). Estes tratamentos foram superiores às combinações de 2,4-D +
BAP de 5:10 e 10:5 em $\mu \mathrm{M}$, os quais não diferiram entre si, mas foram superiores àqueles em que foi acrescido o BAP a $5 \mu \mathrm{M}$ e a $10 \mu \mathrm{M}$. O aspecto dos calos quanto às notas foi semelhante ao observado anteriormente, aos 45 dias. Entretanto, o desenvolvimento dessas estruturas foi maior aos 90 dias (Figura 2), o que fez com que fosse incluída a nota 4 na escala.

A variável incremento da formação calogênica foi a que mostrou a melhor estratificação dos resultados. As combinações de 2,4-D + BAP de 5:5 e 5:10 em $\mu \mathrm{M}$ forneceram resultados superiores aos demais tratamentos e não diferiram entre si. Inclusive, a última combinação mostrou resposta distinta quando comparada com o resultado referente à variável nota (Tabela 2).

Para a formação de raízes nos calos, o melhor tratamento correspondeu à adição de $10 \mu \mathrm{M}$ de ANA ao meio nutritivo, que resultou em $33,3 \%$ de calos rizogênicos, sendo significativamente superior aos demais. A combinação $10 \mu \mathrm{M}$ de 2,4-D + $10 \mu \mathrm{M}$ de BAP apresentou $13,3 \%$ de raízes formadas, destacando-se em relação aos outros, mas inferior ao emprego de ANA a $10 \mu \mathrm{M}$. Os demais tratamentos não induziram à formação de raízes nos calos. 
Tabela 2. Efeito de diferentes balanços dos fitorreguladores: ácido naftalenoacético (ANA), ácido 2,4-diclorofenóxiacético (2,4D) e 6-benzilaminopurina (BAP) adicionados ao meio nutritivo MS sobre a formação de calos rizogênicos e não rizogênicos e o incremento da massa dos calos (\%) em discos foliares de Eugenia involucrata, após 90 dias de cultivo in vitro.

Table 2. Effect of different growth regulators balances: naphthaleneacetic acid (ANA), 2,4-dichlorophenoxyacetic acid (2,4-D) and 6-benzylaminopurine (BAP) added to MS nutrient medium MS on rhizogenic and non-rhizogenic callus formation and increase on callus mass (\%) in leaf discs of Eugenia involucrata, after 90 days of in vitro culture.

\begin{tabular}{cccc}
\hline Tratamentos & Nota & Incremento dos calos (\%) & Calos rizogênicos (\%) \\
\hline $5 \mu \mathrm{M}$ de ANA & $2,87 \mathrm{a}$ & $73,0 \mathrm{c}$ & $0,0 \mathrm{c}$ \\
$5 \mu \mathrm{M}$ de BAP & $1,11 \mathrm{c}$ & $32,3 \mathrm{~d}$ & $0,0 \mathrm{c}$ \\
$10 \mu \mathrm{M}$ de ANA & $2,94 \mathrm{a}$ & $72,6 \mathrm{c}$ & $33,3 \mathrm{a}$ \\
$10 \mu \mathrm{M}$ de BAP & $0,99 \mathrm{c}$ & $32,6 \mathrm{~d}$ & $0,0 \mathrm{c}$ \\
$5 \mu \mathrm{M}$ de ANA $+5 \mu \mathrm{M}$ de BAP & $2,93 \mathrm{a}$ & $74,8 \mathrm{~b}$ & $\mathrm{c}$ \\
$5 \mu \mathrm{M}$ de ANA $+10 \mu \mathrm{M}$ de BAP & $2,39 \mathrm{a}$ & $0,0 \mathrm{c}$ \\
$10 \mu \mathrm{M}$ de ANA $+5 \mu \mathrm{M}$ de BAP & $2,86 \mathrm{a}$ & $0,0 \mathrm{c}$ \\
$10 \mu \mathrm{M}$ de ANA $+10 \mu \mathrm{M}$ de BAP & $2,99 \mathrm{a}$ & $75,1 \mathrm{~b}$ & $0,0 \mathrm{c}$ \\
$5 \mu \mathrm{M}$ de $2,4-\mathrm{D}+5 \mu \mathrm{M}$ de BAP & $3,44 \mathrm{a}$ & $76,4 \mathrm{~b}$ & $\mathrm{c}$ \\
$5 \mu \mathrm{M}$ de $2,4-\mathrm{D}+10 \mu \mathrm{M}$ de BAP & $2,24 \mathrm{~b}$ & $80,3 \mathrm{a}$ & $0,0 \mathrm{c}$ \\
$10 \mu \mathrm{M}$ de $2,4-\mathrm{D}+5 \mu \mathrm{M}$ de BAP & $1,88 \mathrm{~b}$ & $82,4 \mathrm{a}$ & $0,0 \mathrm{c}$ \\
$10 \mu \mathrm{M}$ de $2,4-\mathrm{D}+10 \mu \mathrm{M}$ de BAP & $2,73 \mathrm{a}$ & $75,9 \mathrm{~b}$ & $13,3 \mathrm{~b}$ \\
\hline Média & 2,45 & $77,2 \mathrm{~b}$ & 3,9 \\
\hline $\mathrm{CV}(\%)$ & 8,84 & 68,5 & 9,4 \\
\hline
\end{tabular}

*Médias seguidas pela mesma letra na coluna não diferem entre si pelo teste de Scott-Knott a 5\% de probabilidade de erro.

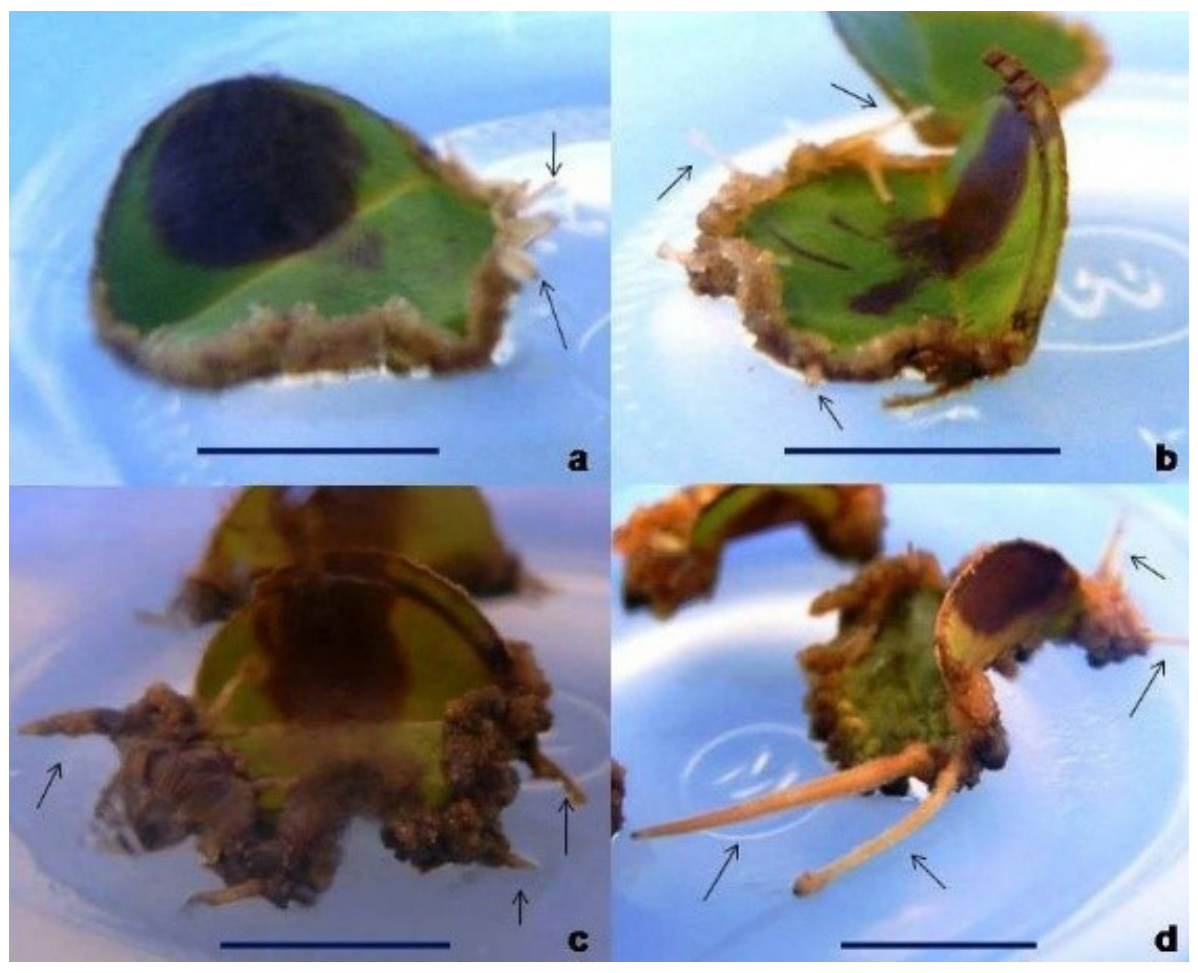

Figura 2. Aspectos da rizogênese em calos formados a partir de discos foliares de Eugenia involucrata. Em "a" e "b" - raízes após 45 dias de cultivo in vitro em meio de cultura MS, e em "c" e "d" - após 90 dias de cultivo. As setas indicam algumas das formações rizogênicas. Barra $=1 \mathrm{~cm}$.

Figure 2. Aspects of rhizogenesis in calli formed from leaf discs of Eugenia involucrata. In "a" and "b" - roots, after 45 days of in vitro culture in MS culture medium, and in "c" and "d" - after 90 days of culture. The arrows indicate some of the rhizogenic formations. Bar $=1 \mathrm{~cm}$. 


\section{Discussão}

No primeiro experimento, a oxidação fenólica não foi afetada pelo emprego de fitorreguladores e apresentou uma reduzida média geral, o que é desejável, já que sua presença pode inviabilizar o crescimento e o desenvolvimento dos explantes. Foram visualizadas pequenas oxidações e alterações de coloração, as quais, entretanto, não comprometeram o crescimento dos calos.

A citocinina BAP, nas concentrações testadas e na ausência de auxinas, não promoveu a formação de calos nos discos foliares. Por outro lado, em estudo conduzido por Morais et al. (2014) com segmentos nodais isolados de plântulas estabelecidas in vitro da espécie Mentha $x$ Piperita, o meio MS contendo BAP a 2 ou a $4 \mathrm{mg}$ $\mathrm{L}^{-1}$ apresentou maior percentual de calogênese $(89,6 \mathrm{e}$ $88,1 \%$ respectivamente). Provavelmente, este resultado foi observado devido às altas concentrações utilizadas, sendo sugerido pelos autores que, com concentrações abaixo de $2 \mathrm{mg} \mathrm{L}^{-1}$ de BAP, este efeito talvez não fosse verificado.

A combinação 2,4-D e BAP em concentrações iguais promoveu a formação de calos nos discos foliares, ratificando a teoria do balanço hormonal, que preconiza que concentrações próximas de auxina e citocinina favorecem a calogênese (Taiz et al., 2017). Em bulbilhos de Agave sisalana houve excelentes respostas para a indução de calos cultivados na presença de 2,4-D e BAP, demonstrando que os fitorreguladores são cruciais para a formação de calos (Carneiro et al., 2014).

A auxina ANA a $10 \mu \mathrm{M}$ proporcionou formação de raízes nos calos, resultado que reforça a teoria referente ao balanço entre reguladores de crescimento. É esperado que concentrações elevadas de auxinas induzam à rizogênese (Taiz et al., 2017), além de servir como indicativo da capacidade de resposta morfogênica dos explantes. Sorin et al. (2005) relataram que a formação de raízes adventícias é um processo complexo, pois envolve múltiplos fatores endógenos da planta, reguladores de crescimento e fatores ambientais, como, por exemplo, a luminosidade. Nesse sentido, as auxinas são classificadas como hormônios que exercem maior influência na indução de raízes adventícias (Pacurar et al., 2014).

No segundo experimento, novamente, não houve efeitos significativos dos tratamentos sobre a oxidação fenólica, observando-se reduzida média geral. Além disso, a oxidação, quando presente, não prejudicou visualmente o crescimento dos explantes.
Em explantes foliares de Salyx humboldtiana, a utilização de ANA na ausência de BAP privilegiou, assim como no presente estudo, o desenvolvimento dos calos, enquanto que o uso isolado da citocinina não foi favorável (Santos et al., 2005). Esses autores observaram que combinações de ANA + BAP foram mais favoráveis à calogênese, especialmente quando a proporção de ANA foi mais elevada em relação à de BAP. O mesmo foi verificado para Hyptis leucocephala, em que a indução calogênica, em segmentos foliares, ocorreu na presença de ANA + BAP (Pereira et al., 2012).

A utilização de 2,4-D aplicado a explantes foliares de Ocimum basilicum L. cv. 'Maria Bonita' também proporcionou a indução de calos (Rosado et al., 2009). Pode se obter calos embriogênicos de Passiflora cincinnata (Silva et al., 2009; Pinto et al., 2010) e de $P$. edulis (Pinto et al., 2011; Rocha \& Dornelas, 2015) em meio de cultura com 2,4-D e BAP.

Diferente dos resultados obtidos em cerejeirado-mato em que a combinação de 2,4-D e BAP foi favorável à formação de calos nos explantes somente com proporções iguais, em segmentos foliares da espécies florestal Blighia sapida, a maior porcentagem de resposta calogênica dos explantes aos reguladores de crescimento ocorreu quando a concentração de 2,4-D foi cerca de quatro vezes maior do que a de BAP (Webster et al., 2006).

Em alguns casos, as raízes surgiram diretamente a partir dos explantes, evidenciando a ocorrência de organogênese direta, que se caracteriza pela ausência de uma etapa de calogênese (Grattapaglia \& Machado, 1998). Além disso, espera-se que a auxina, como observado, seja responsável em níveis elevados pela formação de raízes, já que a rizogênese adventícia está associada às atividades auxínicas (Taiz et al., 2017). Na espécie lenhosa Morinda citrifolia, o uso de ANA permitiu a formação de raízes em explantes foliares (Baque et al., 2010). Esses autores também observaram enraizamento com o uso do ácido indolbutírico (AIB), além de auxina. Esses resultados são semelhantes aos observados no presente trabalho.

Embora os calos não tenham originado brotações, a presença de raízes mostrou a existência de determinação e competência celular para a neorganogênese, sendo possível a morfogênese em tecidos calogênicos de cerejeira-do-mato. De acordo com Termignoni (2005), compreende-se por neorganogênese a formação de novo de estruturas organizadas, denominadas órgãos. 
Não obstante, embora seja conhecido que os diferentes órgãos e tecidos apresentam diferentes respostas in vitro, estes resultados podem servir como referenciais para a rizogênese em cerejeira-do-mato. A rizogênese adventícia exerce um papel fundamental na propagação vegetativa em espécies lenhosas, sendo o enraizamento adventício estratégico para a indústria florestal. Nesse contexto, fitorreguladores, compostos fenólicos, características genéticas e estado nutricional atuam de forma marcante sobre esta rota (Fett-Neto et al., 2001).

\section{Conclusão}

É possível mediar processos de desdiferenciação e rediferenciação celular a partir de discos foliares de cerejeira-do-mato. Para a obtenção de calos em discos foliares de cerejeira-do-mato, as melhores combinações de fitorreguladores envolvem ácido 2,4-diclorofenóxiacético (2,4-D) + 6-benzilaminopurina (BAP) nas proporções, de 5:5 e 10:10 em $\mu \mathrm{M}$. A utilização de $10 \mu \mathrm{M}$ de ácido naftalenoacético (ANA) induz o surgimento de raízes em calos oriundos de discos foliares após 45 dias de cultivo. Aos 90 dias, as raízes podem ser induzidas por meio da inclusão, ao meio de cultura MS, de $10 \mu \mathrm{M}$ de ANA ou da associação de 10 $\mu \mathrm{M}$ de 2,4-D + $10 \mu \mathrm{M}$ de BAP.

\section{Agradecimentos}

O presente trabalho foi realizado com apoio da Coordenação de Aperfeiçoamento de Pessoal de Nível Superior - Brasil (CAPES) - Código de Financiamento 001 e do Conselho Nacional de Desenvolvimento Científico e Tecnológico (CNPq).

\section{Referências}

Alencar, D. R. C. Calogênese e regeneração in vitro de brotos a partir de raiz, entrenó e disco foliar de Brosimum gaudichaudii Tréc. (Moraceae). Revista Eletrônica de Biologia, v. 8, n. 3, p. 288-298, 2015.

Aragão, A. K. O. et al. O efeito do BAP (6-benzilaminopurina) sobre a indução de brotos em explantes de pau-brasil. Cerne, v. 17, n. 3, p. 339-345, 2011. http://dx.doi.org/10.1590/S010477602011000300007.

Backes, P. \& Irgang, B. Árvores do Sul: guia de identificação e interesse ecológico. Porto Alegre: Paisagem do Sul, 2009. 325 p.
Baque, M. A. et al. Induction mechanism of adventitious root from leaf explants of Morinda citrifolia as affected by auxin and light quality. In vitro Cellular and Developmental Biology - Plant, v. 46, n. 1, p. 71-80, 2010. https://doi.org/10.1007/s11627-009-9261-3.

Carneiro, F. S. et al. Embriogênese somática em Agave sisalana Perrine: indução, caracterização anatômica e regeneração. Pesquisa Agropecuária Tropical, v. 44, n. 3, p. 294-303, 2014. http://dx.doi. org/10.1590/S1983-40632014000300005.

Carvalho, M. A. F. et al. Indução, análises morfológicas e ultraestruturais de calos de maracujazeiro nativo. Ceres, v. 62, n. 4, p. 340-346, 2015. http://dx.doi.org/10.1590/0034-737X201562040002.

Carvalho, P. E. R. (Ed.). Espécies arbóreas brasileiras. Brasília, DF: Embrapa Informação Tecnológica; Colombo: Embrapa Florestas, 2014. 634 p. (Coleção espécies arbóreas brasileiras, v. 5).

Ferreira, D. F. Sisvar: a computer statistical analysis system. Ciência e Agrotecnologia, v. 35, n. 6, p. 1039-1042, 2011. http://dx.doi.org/10.1590/S1413-70542011000600001.

Fett-Neto, A. G. et al. Distinct effects of auxin and light on adventitious root development in Eucalyptus saligna and Eucalyptus globulus. Tree Physiology, v. 21, n. 7, p. 457- 464, 2001. http://dx.doi.org/10.1093/treephys/21.7.457.

Grattapaglia, D. \& Machado, M. A. Micropropagação. In: Torres, A. C. et al. Cultura de tecidos e transformação genética de plantas. Brasília, DF: Embrapa-SPI: Embrapa-CNPH, 1998. p. 183-260.

Lorenzi, H. (Ed). Árvores brasileiras: manual de identificação e cultivo de plantas arbóreas nativas do Brasil. 3. ed. Nova Odessa: Instituto Plantarum, 2009. 384 p. v. 2.

$\mathrm{Ma}, \mathrm{X}$. Y. et al. Leaf callus induction and suspension culture establishment in lychee (Litchi chinensis Sonn.) cv. Huaizhi. Acta Physiologiae Plantarum, v. 31, n. 2, p. 401-405, 2009. http://dx.doi. org/10.1007/s11738-008-0223-x.

Morais, T. P. et al. Reguladores de crescimento vegetal no cultivo in vitro de Mentha x Piperita L. Revista Brasileira de Plantas Medicinais, v. 16, n. 2, supl. I, p. 350-355, 2014. http://dx.doi. org/10.1590/1983-084X/13_017.

Murashige, T. \& Skoog, F. A revised medium for rapid growth and bio assays with tobacco tissue cultures. Physiologia Plantarum, v. 15, n. 3, p. 473-497, 1962. https://doi.org/10.1111/j.1399-3054.1962. tb08052.x.

Pacurar, D. I. et al. Auxin is a central player in the hormone crosstalks that control adventitious rooting. Physiologia Plantarum, v. 151, n. 1, p. 83-96, 2014. https://doi.org/10.1111/ppl.12171.

Pasquali, G. \& Zanettini, M. H. B. Transgênese florestal. In: BORÉM, A. Biotecnologia florestal. Viçosa, MG: Ed. UFV, 2007. p. 317-334.

Pereira, D. M. S. et al. Induction and morphological and biochemical characterization of Hyptis leucocephala (Lamiaceae) calluses. Sitientibus série Ciências Biológicas, v. 12, n. 1, p. 151156, 2012. https://doi.org/10.13102/scb124.

Pinto, D. L. P. et al. Ploidy stability of somatic embryogenesis-derived Passiflora cincinnata Mast. plants as assessed by flow cytometry. Plant Cell, Tissue and Organ Culture, v. 103, n. 1, p. 71-79, 2010. https://doi.org/10.1007/s11240-010-9756-y. 
Pinto, D. L. P. et al. Somatic embryogenesis from mature zygotic embryos of commercial passionfruit (Passiflora edulis Sims) genotypes. Plant Cell, Tissue and Organ Culture, v. 107, n. 3, p. 521-530, 2011. https://doi.org/10.1007/s11240-011-0003-y.

Rocha, D. I. \& Dornelas, M. C. Alternative induction of de novo shoot organogenesis or somatic embryogenesis from in vitro cultures of mature zygotic embryos of passion fruit (Passiflora edulis Sims) is modulated by the ratio between auxin and cytokinin in the medium. Plant Cell, Tissue and Organ Culture, v. 120, n. 3, p. 1087-1098, 2015. https://doi.org/10.1007/s11240-014-0663-5.

Rosado, L. D. S. et al. Aspectos do cultivo in vitro do manjericão cv. Maria Bonita (Ocimum basilicum L.). Plant Cell Culture \& Micropropagation, v. 5, n. 2, p. 71-78, 2009.

Rossato, M. et al. Multiplication and in vitro rooting of Campomanesia adamantium Camb. Plant Cell Culture \& Micropropagation, v. 11, n. 2, p. 70-77, 2015.

Santos, B. R. et al. Indução de calos friáveis em explantes foliares de salix (Salyx humboldtiana Willd). Ciência Rural, v. 35, n. 3, p. 510514, 2005. http://dx.doi.org/10.1590/S0103-84782005000300004.

Shen, X. et al. Assessment of somaclonal variation in Dieffenbachia plants regenerated through indirect shoot organogenesis. Plant Cell, Tissue and Organ Culture, v. 91, n. 1, p. 21-27, 2007. https://doi. org/10.1007/s11240-007-9273-9.
Silva, M. L. et al. A novel regeneration system for a wild passion fruit species (Passiflora cincinnata Mast.) based on somatic embryogenesis from mature zygotic embryos. Plant Cell, Tissue and Organ Culture, v. 99, n. 1, p. 47-54, 2009. https://doi.org/10.1007/ s11240-009-9574-2.

Sorin, C. et al. Auxin and light control of adventitious rooting in Arabidopsis require Argonaute. The Plant Cell, v. 17, n. 5, p. 1343 - 1359, 2005. https://doi.org/10.1105/tpc.105.031625.

Stachevski, T. W. et al. Efeito do meio de cultura na calogênese in vitro a partir de folhas de erva-mate. Pesquisa Florestal Brasileira, v. 33, n. 75, p. 339-342, 2013. https://doi.org/10.4336/2013. pfb.33.75.441.

Taiz, L. et al. Fisiologia e desenvolvimento vegetal. 6. ed. Porto Alegre: Artmed, 2017. 888 p.

Termignoni, R. R. Cultura de tecidos vegetais. Porto Alegre: Ed da UFRGS. 2005. 182 p.

Webster, S. A. et al. Somatic embryogenesis from leaf and zygotic embryo explants of Blighia sapida "cheese" ackee. In Vitro Cellular \& Developmental Biology - Plant, v. 42, n. 5, p. 467-472, 2006. https://doi.org/10.1079/IVP2006795.

Werner, E. T. et al. Meios de cultura, reguladores de crescimento e fontes de nitrogênio na regulação da calogênese do pau-brasil (Caesalpinia echinata Lam.). Acta Botânica Brasileira, v. 24, n. 4, p. 1046-1051, 2010. http://dx.doi.org/10.1590/S010233062010000400019 . 